\title{
Exciting Years Ahead for NRR
}

\author{
Emmanuel John M. Carranza ${ }^{1,2,3}$
}

With the acceptance of Natural Resources Research (NRR) in February 2017 for inclusion in the Science Citation Index Expanded ${ }^{\mathrm{TM}}$ (also known as SciSearch ${ }^{\circledR}$ ), Journal Citation Reports ${ }^{\circledR}$ (JCR) Science Edition, and Current Contents ${ }^{\circledR} /$ Physical Chemical and Earth Sciences, our first impact factor will be evaluated based on citations to papers published in 2015 and 2016 and will be released sometime in the middle of this year 2018. Indeed we are so excited about this development because being included in SciSearch ${ }^{\circledR}$ and JCR is a significant acknowledgment of the high standard of our journal. It also depicts the culmination of the development of our journal since it was founded in 1992 by Richard McCammon. Its immediate positive effect is the more than $130 \%$ increase in the number of manuscripts that we have received this year 2017 compared to those in each of the preceding years (Fig. 1). This reflects that, indeed, most researchers submit their papers for publications mainly to journals included in SciSearch ${ }^{\circledR}$. Therefore, we are looking forward to the potential growth of our journal in the years to come.

However, because of poor quality, we have rejected at least $77 \%$ of the more than 200 manuscripts that we have received this year (Fig. 1). About 46\% of the manuscripts that we have rejected were not even sent out for peer review because they contain text with significant similarity to text in the published literature. This reflects how rampant plagiarism is being practiced among researchers, probably because of either the pressure from the "publish or

\footnotetext{
${ }^{1}$ School of Agricultural, Earth and Environmental Sciences, University of KwaZulu-Natal, Durban, South Africa.

${ }^{2}$ Economic Geology Research Centre (EGRU), James Cook University, Townsville, QLD, Australia.

${ }^{3}$ To whom correspondence should be addressed; e-mail: ejmcarranza@gmail.com
}

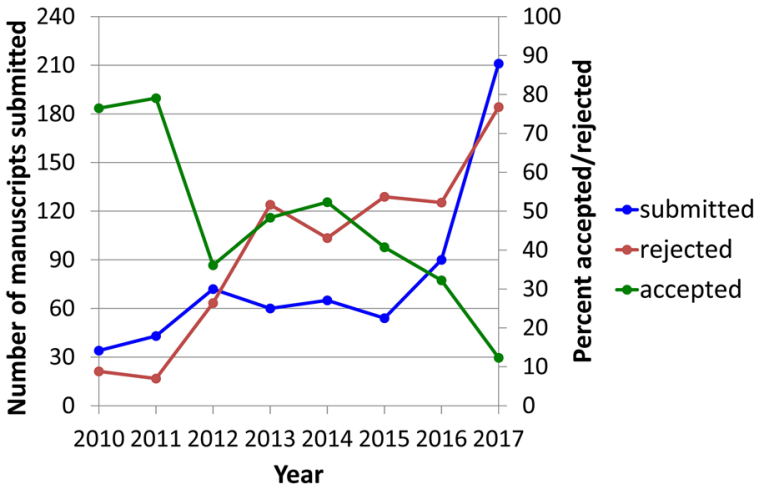

Figure 1. Annual numbers of manuscripts submitted to NRR, and annual rejection and acceptance rates.

perish" policy in academic/research institutions or the difficulty to write in English. Therefore, regardless of the potentially increasing number of manuscripts we will receive in the years to come, we will strive to maintain or even improve the high standard of our journal. Fortunately, and thanks to the text recognition software provided to us by the publisher, we are able to check the potential plagiarism immediately.

The very abrupt increase in manuscripts submitted to our journal this year is a very good sign that our journal will have a growing readership. To sustain that, we will certainly continue to publish high-quality papers on up-to-date and cutting-edge researches. In addition, we will publish special issues on hot topics. In 2017, we published a special issue on GIS-Based Geochemical Anomaly and Mineral Prospectivity Mapping with 11 articles. Just after a few months of their publication, each of those 11 articles now has at least one citation (according to Google Scholar); one article has been cited six times, and two have been cited five times. This reflects the strong interest among NRR's readership on the topic of the 2017 special issue. 
This year 2018 we will publish a special issue on Mineral Resources of the Future. Currently, we are in the acquisition stage to run a special issue on Forests, Agriculture and Environmental Protection as a Path to Sustainable Development, and we hope to publish this in 2019. We will endeavor to publish at least one special issue of articles every year because we believe, per experience although not necessarily with NRR, that special issue articles are excellent highimpact generators for many journals. So, if there are readers of NRR who are interested to propose special issues of hot-topic articles and be the guest editors of such special issues, please contact me.

Afzal, P.

Agterberg, F. (3)

Ahmadi, S.H.

Akhzari, D.

Akinci, $\mathrm{H}$.

Alam, J.M.

Allanore, A.

Almeida, J.A.

Ambrose, W.

Anderson, S.T.

Andrews-Speed, P.

Ansari, M.A.

Armstrong, $\mathrm{M}$.

Ataee-pour, M.

Attanasi, E.

Azam, F.

Barandun, $\mathrm{M}$.

Beirandvand Pour, A.

Bhattacharya, A.

Boisvert, J.

Buccianti, A.

Carr, J.R.

Carranza, E.J.M.

Castro, L.

Cerqueira Koppe, V.

Chakraborty, T.

Chatterjee, S.

Clarke, R.

Coburn, T. (2)

Cocker, M.D.

Coimbra Leite Costa, J.F.

Comunian, A.

Costafreda, S.

Coto, B.

Cracknell, M.J. (2)

Craddock, $\mathrm{P}$.
Moreover, if the number of high-quality manuscripts submitted continues to grow, we may increase the number of issues published per year, but this remains to be seen in the coming years and particularly after the release of our first impact factors.

As usual, improving and maintaining the standard of papers in this journal depend on the selfless time and effort of the many scientists who review manuscripts. Therefore, we acknowledge with sincere gratitude the following individuals for reviewing manuscripts submitted to our journal during 2017, especially those who have reviewed more than one manuscript (as indicated by numbers in parentheses).

Czarnota, R.

Dag, A.

Deutsch, C. (2)

Dewulf, J.

Dogan, $\mathrm{M}$.

Eggert, R.

Ekinci, Y.L.

Elshaki, A.

Emery, X. (3)

Erdmann, L.

Fan, S.

Favas, P.

Förter, A.

Fouedjio, F. (2)

George, N.J. (2)

Gonçalves, M. (3)

Gosnold, W.

Guellala, R. (2)

Gunn, A.G.

Guo, F.

Hamak, J.E.

Hanberry, B.B.

Hanhøj, K.

Henckens, M.L.C.M.

Henley, S.

Höök, M.

Huang, W.

Hundelshaussen, R.

Jafrasteh, B.

Jaganathan, C.

Jain, P.K.

Jaiswal, R.K.

Jalali, M. (2)

Jamieson, H.E.

Jirásek, J.

Kaiser, M. 
Kartha, S.J. (2)

Kirkwood, C.

Koike, K. (2)

Krishan, G.

Kuchuk, F.J.

Kuma, J.S.

Kumar, S.

Kumral, M. (2)

Laurent, G.

Lee, J.-Y.

Lemiere, B.

Leslie, $\mathrm{K}$.

Levine, $\mathrm{C}$.

Lilford, E.

Lisitsin, V. (2)

Liu, Y. (2)

$\mathrm{Ma}, \mathrm{X}$.

Ma, X.-G.

Madani, N.

Malehmir, A.

Marcotte, D.

Matsumoto, K.

Michaelides, S. (2)

Misra, A.K.

Modica, G.

Mogaji, K.A.

Mohanty, D.

Moon, C.

Mudd, G.M.

Northey, S.A.

Nykänen, V.

Pan, G.

Patiño Douce, A.E. (2)

Pauliuk, S.

Pedretti, D.

Peksen, E.

Prol-Ledesma, R.M.

Rahaman, S.A. (2)

Raju, N.J. (3)

Ranjbar, $\mathrm{H}$.

Rasilainen, K.

Rauch-Davies, M.

Raymond, J.

Raziperchikolaee, S.
Roper, L.D.

Ruberti, M.

Sadhavisam, S.

Sahu, B.K.

Samal, A.R. (2)

Samanta, B.

Sarala, P.

Schliep, E.M.

Shivanna, S.

Sides, E.J.

Singer, D.A.

Southam, G.

Stoyan, D.

Strand, G.-H.

Struchkov, I.

Tenerelli, P.

Tercan, E. (2)

Tilton, J.E.

Valero, A.

Valls, R.A.

Valls, R.A.

van der Werff, $\mathrm{H}$.

Vangeepuram, R.

Vasu, D.

Viccaro, M.

Wang, A.

Wang, $\mathrm{H}$.

Wang, Q.

Wang, W.

Webster, R.

Weijermars, R.

Wellmer, F.-W.

Yalew, S.G.

Yamamoto, J.K. (3)

Yigit, O.

Yousefi, M. (2)

Yuan, F.

Zemp, M.

Zhang, B.

Zhang, K.

Zhou, X.

Zhu, L.

Zuo, R. (5) 